\title{
Mitigation of the Wonorejo active fault on the Probolinggo- Banyuwangi toll road
}

\author{
Reza Kazhimi ${ }^{1, *}$ \\ ${ }^{1}$ Manager of Design Control, Technical Division, PT. Jasamarga Probolinggo Banyuwangi, Indonesia
}

\begin{abstract}
As the world's largest archipelago, Indonesia is located between the world's most active seismic region. This situation leads Indonesia to be part of the region that has the highest seismic potential in the world. In recent years, one of the infrastructures that experiences significant development is the toll road. As Indonesia is located in active tectonic areas, it is certainly a challenge in the process of determining the alignment and technical design of the toll road. The original alignment (based on basic design) of Probolinggo-Banyuwangi toll road which is now in the planning stage was passing the Wonorejo fault which is an active fault based on the Seismic Hazard Maps of Indonesia 2017. Because earthquakes are natural events that have not been accurately calculated and estimated, both when and where they occur as well as their magnitude, according to the mitigation strategies for fault rupture suggested by FEMA (Federal Emergency Management Agency), the fault rupture should be avoided, even more, earthquakes have the potential to cause large losses. Based on these considerations, the alignment of the Probolinggo-Banyuwangi toll road is in the process of being submitted for a shift to the east in order to avoid the location of the Wonorejo fault.
\end{abstract}

\section{Introduction}

Disaster is an abrupt adverse or unfortunate extreme event which causes horrific damage to human beings, plants and animals. Disasters occur unpredictably without discrimination in such an instantaneous manner. It is difficult to make adjustment and prediction as these events, regardless whether they are natural or maninduced, always accede the tolerable magnitude or beyond certain limits. As a result, high fatalities, disastrous property losses as well as loss of income are incurred. These events which occur aggravate natural environmental processes cause disasters to human society such as sudden tectonic movements leading to earthquake and volcanic eruptions, continued dry conditions leading to prolonged droughts, floods, atmospheric disturbances, collision of celestial bodies, etc. (Joshi, 2008) [1].

Natural hazards can be catastrophic to life and property. Based on data from BNPB, in 2018, there have been 3397 disasters in Indonesia.

Based on Fig. 1, it can be seen that, from a total of 3397 disasters in 2018, there were 28 earthquakes, which might be not too large if it is seen from the number of cases compared to the total disaster events in Indonesia. However, if it is seen from the impact caused, the earthquake and also tsunami have the greatest impact which can be seen from the loss of life and damage to the building caused.

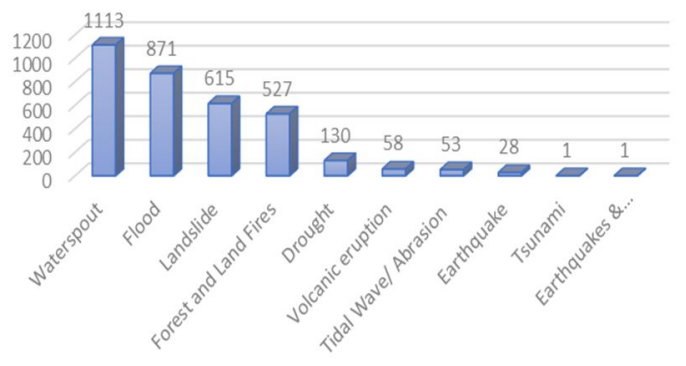

Fig. 1. Number of Disasters in 2018 (www.bnpb.go.id)

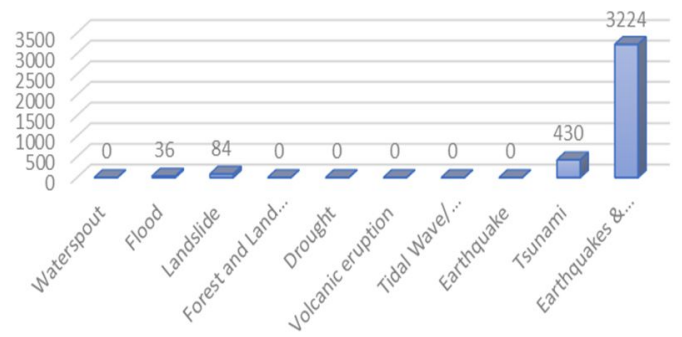

Fig. 2. Dead and Missing Victims in 2018 (www.bnpb.go.id)

\footnotetext{
* Corresponding author: rezakazhimi@gmail.com
} 


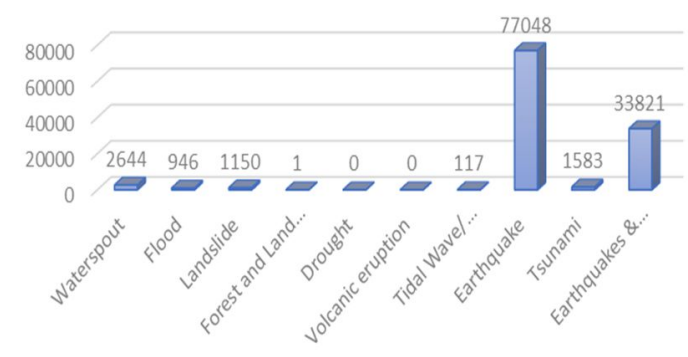

Fig. 3. Severely Damaged Building in 2018 (www.bnpb.go.id)

As shown in Fig. 2 and Fig. 3, it can be seen that the earthquake and tsunami had a large impact, illustrated by the number of fatalities and impacted buildings.

An earthquake is a sudden ground motion or trembling caused by an abrupt release of accumulated strains acting on the tectonic plates that comprise the Earth's crust. They often trigger other devastating events such as lateral spreads, landslides and fires; and damage bridges, buildings, dams and other infrastructure components. An earthquake may also lead to Tsunami to coastal areas if it triggers in the ocean. Although the probability of large destructive earthquakes is relatively much lower than other natural hazards such as hurricanes and floods. An earthquake can, without warning, devastate an area within one to two minutes through ground shaking, surface fault rupture and ground failures [2].

Indonesia is located in the Circum-Pacific belt, also known as the Ring of Fire, and is the most active belt in the world. This area accounts for around $90 \%$ of the world's earthquakes and almost half of them are the world's biggest earthquakes (Kramer, 1996). Based on these seismotonic conditions, seismicity in Indonesia is affected by interactions of the three main plates of the world, namely: the Eurasian plate, the Indo-Australian plate, and the Pacific plate, and several small plates or microblocks, such as Burma, Sunda, Banda Sea, Maluku Sea, Timor, Bird's Head, Maoke, and Woodlark (Atamimi et al., 2011). The interaction between tectonic plates has led Indonesia to be one of the countries in the world with very high seismic activity [3].

In the last 16 years, a number of large earthquake

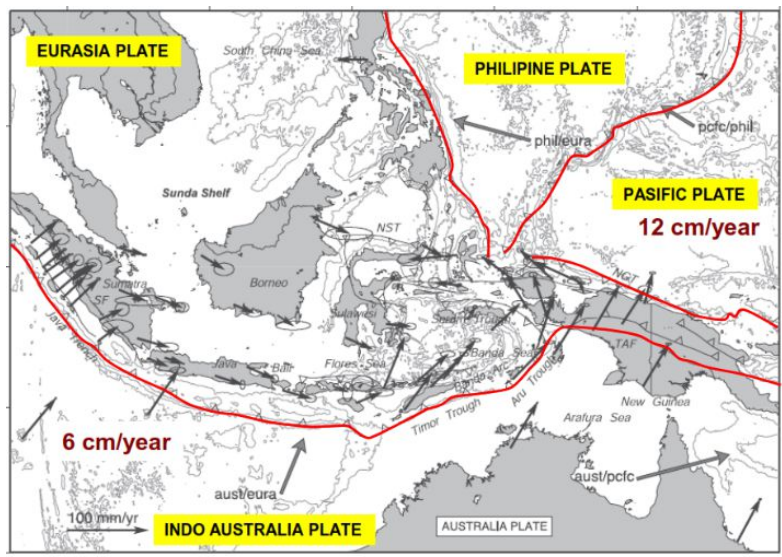

Fig. 4. Major Tectonics around Indonesia (Bock et al., 2003) activities in Indonesia have been recorded: the Aceh Earthquake followed with the tsunami in $2004(\mathrm{Mw}=$ 9.2), the Nias Earthquake in $2005(\mathrm{Mw}=8.7)$, the Yogyakarta Earthquake in $2006(\mathrm{Mw}=6.3$ ), Tasik Earthquake in $2009(\mathrm{Mw}=7.4)$, Padang Earthquake in $2009(\mathrm{Mw}=7.6), 2009$ Jambi Earthquake $(\mathrm{Mw}=6.6)$, 2010 Mentawai Earthquake $(\mathrm{Mw}=7.2)$, Simeuleu Earthquake in $2012(\mathrm{Mw}=8.5)$, Simeuleu Earthquake in $2012(\mathrm{Mw}=8.1)$, and finally Pidie Earthquake $(\mathrm{Mw}=$ 6.5). These earthquakes caused thousands of lives to be lost, collapsed and damaged. thousands of infrastructure and buildings, and losses of hundreds of trillions of rupiah for rehabilitation and reconstruction [3].

Because earthquakes are mostly caused by rupture of geological faults apart from other events such as volcanic activity, landslides, and etc. Therefore, more attention is needed on fault locations in Indonesia.

This paper will discuss mitigation efforts undertaken to address potential hazards caused by an active fault. The methodology used in this paper is to conduct an analysis and evaluation based on available literature and data.

\section{Identification of the Wonorejo Active Fault on The Probolinggo- Banyuwangi Toll Road}

Probolinggo-Banyuwangi Toll Road is the last section of Trans Java Toll Road which connects Probolinggo to Banyuwangi in East Java Province.

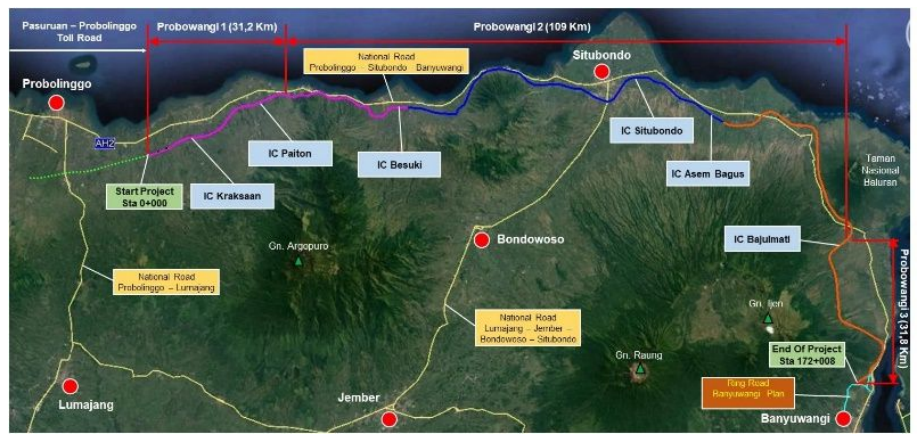

Fig. 5. Original Probolinggo-Banyuwangi Toll Road Alignment

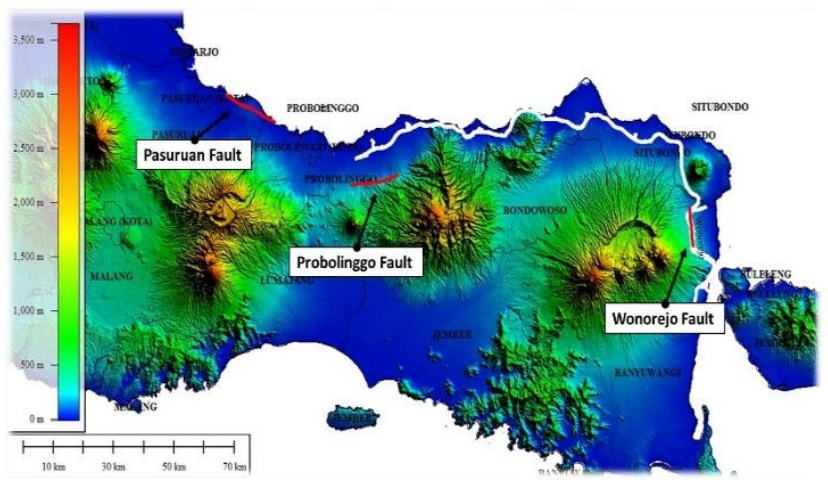

Fig. 6. Probolinggo - Banyuwangi Toll Road Alignment and the location of the Faults (BPPU ITS, 2018) 


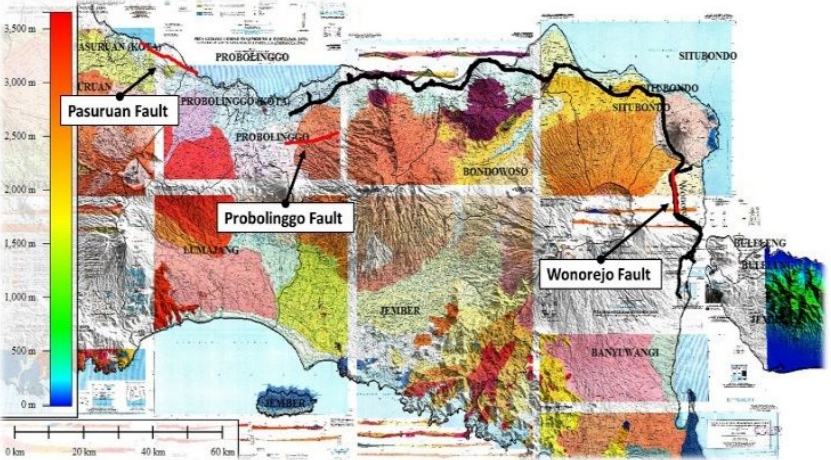

Fig. 7. Geological Map of East Java Province in ProbolinggoBanyuwangi Toll Road (BPPU ITS, 2018)

The results of the 2017 Seismic Hazard Maps of Indonesia update by the Pusat Studi Gempa Nasional (PUSGEN) or National Center for Earthquake Studies, in East Java Province show that there are new active faults, such as Pasuruan Fault, Probolinggo Fault, and Wonorejo Fault. Earthquake mitigation is needed to reduce the danger caused by earthquakes.

Table 1. Data of Active Faults (2017 Seismic Hazard Maps of Indonesia)

\begin{tabular}{|l|l|l|l|l|l|l|l|}
\hline No & $\begin{array}{l}\text { Active } \\
\text { Faults }\end{array}$ & Type & \multicolumn{2}{|l|}{ Location } & $\begin{array}{l}\text { Le } \\
\text { ng } \\
\text { th }\end{array}$ & $\begin{array}{l}\text { Mag } \\
\text { nitud } \\
\text { e }\end{array}$ & $\begin{array}{l}\text { Slip } \\
\text { Rate } \\
\text { Geode } \\
\text { tic } \\
\text { (mm/s } \\
\text { ) }\end{array}$ \\
\cline { 2 - 6 } 1 & $\begin{array}{l}\text { Stri } \\
\text { ke }\end{array}$ & Dip & $\begin{array}{l}\text { (k } \\
\text { m) }\end{array}$ & & & & \\
\hline 2 & $\begin{array}{l}\text { Probolin } \\
\text { ggo }\end{array}$ & SS & - & $60 \mathrm{~N}$ & 15 & 6.5 & 0.2 \\
\hline 3 & $\begin{array}{l}\text { Wonorej } \\
\text { o }\end{array}$ & $\mathrm{N}$ & - & $60 \mathrm{E}$ & 10 & 5.7 & 0.3 \\
\hline
\end{tabular}

The original alignment (based on basic design) of the Probolinggo-Banyuwangi toll road which is now in the planning stage was passing the Wonorejo fault which is an active fault based on the Seismic Hazard Maps of Indonesia in 2017. The location of this fault needs to be watched out, because it is indicated that it is an active fault and it can cause an earthquake. Based on Seismic Hazard Maps of Indonesia in 2017, the maximum magnitude of this fault is 5.7 and the slip rate geodetic is $0.3 \mathrm{~mm} /$ year. Earthquake does not just deal with the strength or magnitude of the earthquake. In the case of this fault, the infrastructures or buildings that stand just above the fault line are in dangerous situation.

There are three important factors used to assess an earthquake's impact. The peak ground acceleration (PGA) is a very important factor in engineering seismology, as it influences how much earthquakeaffected infrastructure is destroyed and its displacement, and it is also the main factor in determining the magnitude of the earthquake. The PGA is mainly affected by the earthquake's magnitude and the distance to the active fault. The second factor, the "population", is a direct index related to the social economics of the region. This variable is also a factor in the relationship between the economy and the amount of infrastructure and the number of buildings in the region. Both factors reflect the earthquake-associated hazard and all elements at risk [4].

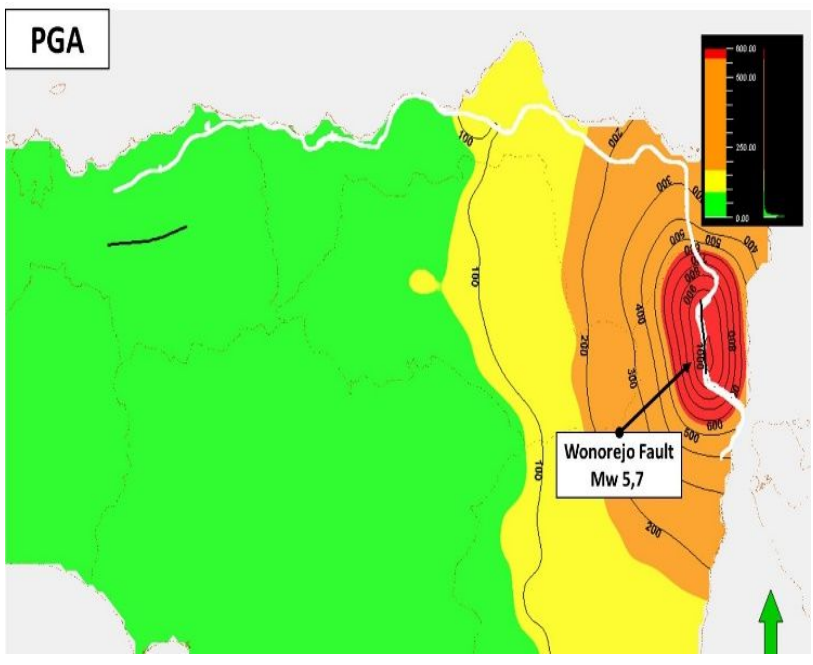

Fig. 8. Magnitude of Wonorejo Fault (BPPU ITS, 2018)

Table 2.BMKG Earthquake Intensity Scale (www.bmkg.go.id)

\begin{tabular}{|c|c|c|c|c|c|}
\hline $\begin{array}{c}\text { BMK } \\
\text { G } \\
\text { Earth } \\
\text { Quake } \\
\text { Intensi } \\
\text { ty } \\
\text { Scale } \\
\end{array}$ & Color & $\begin{array}{c}\text { Simple } \\
\text { Descriptio } \\
\mathbf{n}\end{array}$ & $\begin{array}{c}\text { Detailed } \\
\text { Description }\end{array}$ & $\begin{array}{c}\text { MM } \\
\text { I } \\
\text { Scal } \\
\text { e }\end{array}$ & $\begin{array}{c}\text { PG } \\
\text { A } \\
\text { (gal) }\end{array}$ \\
\hline I & White & Not Felt & $\begin{array}{c}\text { not felt or } \\
\text { felt by only } \\
\text { a few people } \\
\text { but recorded } \\
\text { by the } \\
\text { device }\end{array}$ & I-II & $\begin{array}{c}<2 \\
9\end{array}$ \\
\hline II & Green & Felt & $\begin{array}{l}\text { felt by many } \\
\text { people but } \\
\text { doesn't } \\
\text { cause } \\
\text { damage. } \\
\text { Light } \\
\text { objects hung } \\
\text { swaying and } \\
\text { the glass } \\
\text { window } \\
\text { shook } \\
\end{array}$ & $\begin{array}{l}\text { III- } \\
\text { V }\end{array}$ & $\begin{array}{c}2.9- \\
88\end{array}$ \\
\hline III & $\begin{array}{c}\text { Yello } \\
\text { w }\end{array}$ & $\begin{array}{c}\text { Slight } \\
\text { Damage }\end{array}$ & $\begin{array}{l}\text { the non- } \\
\text { structural } \\
\text { part of the } \\
\text { building } \\
\text { suffered } \\
\text { minor } \\
\text { damage, } \\
\text { such as hair } \\
\text { cracks on } \\
\text { the wall, the } \\
\text { roof shifted } \\
\text { down and } \\
\text { partially fell }\end{array}$ & VI & $\begin{array}{l}89- \\
167\end{array}$ \\
\hline
\end{tabular}



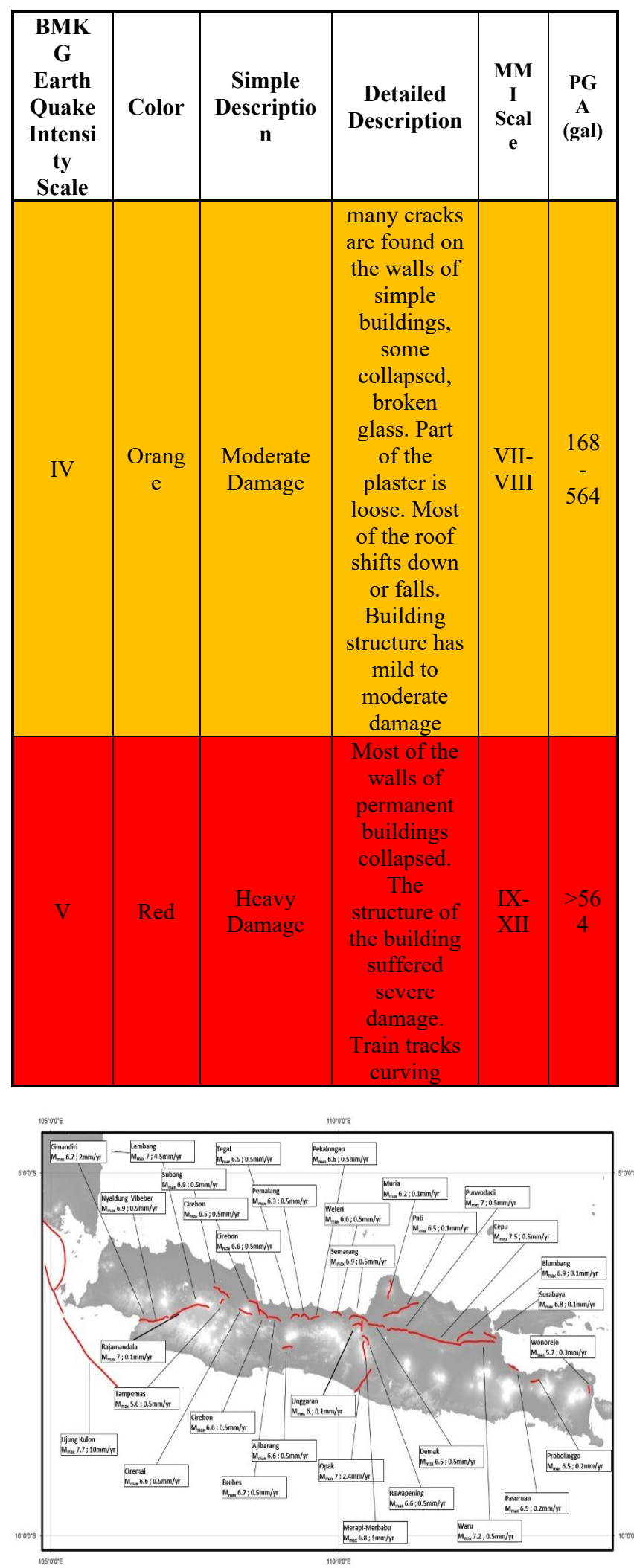

Fig. 9. Earthquake Sources for Indonesian Hazard Maps 2017 - Active Faults (For Java) (Irsyam, 2017, PusGen 2017)

\section{Mitigation of the Wonorejo Active Fault on the Probolinggo- Banyuwangi Toll Road}

As Shown in Fig. 8 and Table 2, the toll road alignment which is located just above the fault line is included in "red zone" that can cause heavy damage; hence, mitigation efforts are needed to reduce the level of risk.

Since earthquakes are natural events that have not been accurately calculated and estimated, both when and where they occur as well as their magnitude. As shown in Table 3, according to the mitigation strategies for fault rupture suggested by FEMA (Federal Emergency Management Agency), the fault rupture should be avoided, even more, earthquakes have the potential to cause large losses.

Table 3. Mitigation Strategies (FEMA 451b, 2017)

\begin{tabular}{|l|l|}
\hline Earthquake Effect & Strategy \\
\hline Fault Rupture & Avoid \\
\hline Tsunami/Seiche & Avoid \\
\hline Landslide & Avoid \\
\hline Liquefaction & Avoid/Resist \\
\hline Ground Shaking & Resist \\
\hline
\end{tabular}

Based on these considerations, the alignment of the Probolinggo-Banyuwangi toll road is in the process of being submitted for a shift in order to avoid the location of the Wonorejo fault.

Of course, there are many disciplines and aspects are involved in earthquake hazard mitigation. All aspects of planning must always be considered to produce a safe and optimum toll road design. This proposed shift in Probolinggo-Banyuwangi Toll Road alignment due to the Wonorejo Fault has to pay attention to other aspects, such as highway geometric, existing utilities, etc.

The main purpose is that this shifted toll road alignment must avoid the location of the Wonorejo fault. Afterwards, this shifted toll road alignment must also consider or adjust to utilities such as the existing $150 \mathrm{kV}$ High Voltage Power Lines and the planned $500 \mathrm{kV}$ Very High Voltage Power Lines. Then, the shifting of this toll road alignment should also pay attention to the side of the geometric design of highways, to avoid the existing location which is relatively high. The proposed alignment is shifted eastward. This is done so that in designing the gradient/slope on the vertical alignment of the toll road can meet the required geometric standards (for design speed:80 $\mathrm{km} / \mathrm{h}$, the maximum allowable slope is $4 \%$ ). Based on these considerations, the proposed toll road alignment is shifted as shown in the Fig. 10. 


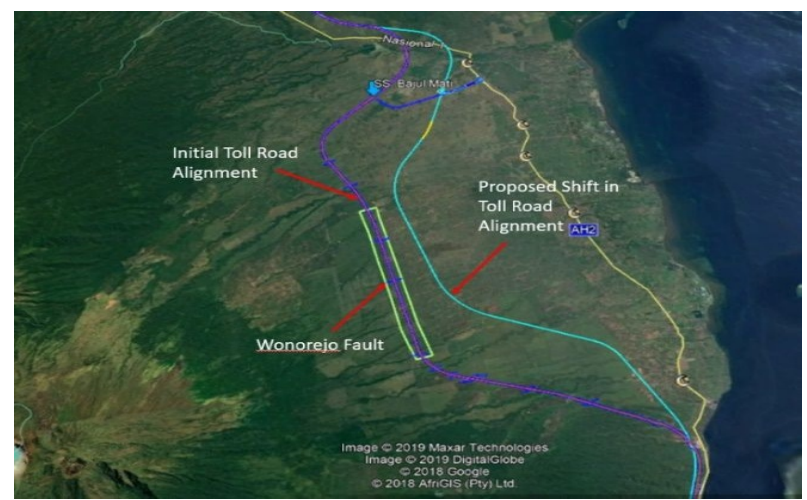

Fig. 10. Proposed Shift in Probolinggo Banyuwangi Toll Road Alignment Due to the Wonorejo Fault

\section{References}

1. Adnan, A., Ramli, MZ., and Abd. Razak, SKM. Disaster Management and Mitigation for Earthquakes: Are We Ready? (2015)

2. W.Phillip Yen. WCEE. Seismic Hazard Mitigation Strategies and Measures of Highway Bridges (2012)

3. M.Irsyam, Peran dan Kontribusi Rekayasa Geoteknik Kegempaan Dalam Upaya Pengurangan Risiko Bencana Gempa Bumi Indonesia Dalam Dekade Terakhir (2017)

4. J.Zuang, J.Peng, X.Zhu, and W.Huang. ISPRS Int. J. Of Geo-Inf. Scenario-Based Risk Assessment of Earthquake Disaster Using Slope Displacement, $P G A$, and Population Density in the Guyuan Region, China (2019) 